auteurs qui souhaitent consulter des exemples de méthode adéquate de revue d'articles peuvent visiter le site Web Evidence-Based Medicine (cebm.jr2.ox.ac.uk) ou consulter des articles publiés dans le ACP Journal Club.

Le rédacteur de la section Articles sélectionnés est le $\mathrm{D}^{\mathrm{r}}$ David Rhine, Department of Emergency Medicine, King Faisal Specialist Hospital and Research Center; PO Box 3354, MBC 84, Riyadh 11211, Saudi Arabia; fax 966-1442-1436; drhine@ hotmail.com.

Les RCS et les revues d'articles sélectionnés doivent être soumises au rédacteur de section approprié. La pertinence pour publication dans le $J C M U$ sera déterminée à partir de la qualité de la revue et du niveau d'intérêt du sujet pour les urgentologues. Pour d'autres directives, consultez les «Instructions for Authors» (page 77).

\section{References}

1. Oxman AD, Sackett DL, Guyatt GH. The Evidence-Based Medicine Working Group. Users' guides to the medical literature: how to get started. JAMA 1993;270:2093-5.

2. Guyatt GH, Sackett DL, Cook DJ. The Evidence-Based Medicine Working Group. Users' guides to the medical literature: how to use an article about therapy or prevention. Are the results of the study valid? JAMA 1993;270:598-601.

3. Guyatt GH, Sackett DL, Cook DJ. The Evidence-Based Medicine Working Group. Users' guides to the medical literature: how to use an article about therapy or prevention. What were the results and will they help me in caring for my patients? JAMA 1994;271:59-63.

4. Dans AL, Dans LF, Guyatt GH, Richardson S. The EvidenceBased Medicine Working Group. Users' guides to the medical literature: how to decide on the applicability of clinical trial results. JAMA 1998;279:545-9.

\title{
Critically ApPraised Topics
}

\section{Are inhaled corticosteroids useful in the emergency department treatment of acute asthma?}

\begin{abstract}
Article chosen
Rodrigo G, Rodrigo C. Inhaled flunisolide for acute severe asthma [see comment]. Am J Respir Crit Care Med 1998; 157:698-703.
\end{abstract}

\section{Clinical bottom line}

This study shows that, in patients receiving inhaled salbutamol in the emergency department (ED), the addition of highdose flunisolide (Bronalide; Boehringer Ingelheim, Burlington, Ont.) significantly improves peak expiratory flow rate (PEFR) and forced expiratory volume in 1 minute $\left(\mathrm{FEV}_{1}\right)$ compared with placebo. There was a trend toward decreased admission rate in the flunisolide group that may be clinically significant but did not achieve statistical significance. We do not know if there is an additive effect of oral or intravenous steroids. Other trials have shown conflicting results.

\section{The search}

A MEDLINE search, 1995 to 1998 , using the following MeSH headings:

1. $\exp /$ asthma

2. exp/ anti-inflammatories, steroidal

16770

3. exp/ double-blind method
Reviewer

Marcia Edmonds, MD,

University of Alberta, Edmonton, Alta.

Date appraised: Dec. 15, 1998

This article has been peer reviewed.

4. $\exp /$ emergencies

3325

5. 1 AND 2 AND 3 AND 4

\section{The evidence}

Design: Randomized, double-blind trial.

Population: Ninety-four patients aged 18 to 50 years who presented to the ED with an exacerbation of asthma (with $\mathrm{FEV}_{1}$ and PEFR $\leq 50 \%$ of predicted). The treatment groups were similar in all baseline demographic and clinical variables reported.

Intervention: Flunisolide $1 \mathrm{mg}$ and salbutamol $400 \mu \mathrm{g}$ $q 10 \mathrm{~min}$. versus salbutamol alone $400 \mu \mathrm{g} q 10 \mathrm{~min}$. All treatments were by multi-dose inhaler with spacer.

Outcomes measured: $\mathrm{FEV}_{1}$, PEFR, respiratory rate, heart rate, accessory-muscle use, dyspnea and wheezing were measured at 30-minute intervals for 3 hours after presentation. Side effects (nausea, palpitations, tremor, anxiety and 
headache) and admission rates were compared at the end of therapy.

Results: The flunisolide group had significantly better PEFR at 90, 120, 150 and 180 minutes, and better $\mathrm{FEV}_{1}$ at 120, 150 and 180 minutes than did the placebo-treated group. The difference between groups increased with time. Four flunisolide-treated patients and 12 placebo-treated patients required admission $(8.5 \%$ v. $25.5 \%$; number needed to treat $[\mathrm{NNT}]=6$ ). A difference of this magnitude would be clinically significant, but given the sample size, this outcome did not achieve statistical significance. Subgroup analysis showed that placebo-treated patients whose symptom duration was greater than 24 hours had significantly lower $\mathrm{FEV}_{1}$ and higher clinical scores (including dyspnea, wheezing and accessory muscle use) at 120,150, and 180 minutes than flunisolide-treated patients (regardless of symptom duration) or placebo-treated patients with symptom duration less than 24 hours. There was no difference in adverse effects between treatment and control groups.

\section{Comments}

Study patients did not receive oral or intravenous corticosteroids, so we cannot determine whether inhaled corticosteroids have an additive effect to intravenous or oral corticosteroids. Study patients received a particularly high dose of flunisolide ( $6 \mathrm{mg} / \mathrm{h}$ over 3 hours; total, $18 \mathrm{mg}$ ). The usual dose recommended for maintenance is 1 to $2 \mathrm{mg} / \mathrm{d}$. The cost of a flunisolide inhaler containing $25 \mathrm{mg}(100 \times$
$250 \mu \mathrm{g}$ ) is $\$ 15$. The cost of one 50 -mg prednisone tablet is $\$ 0.07$. Other studies have found conflicting results: Sung and colleagues ${ }^{1}$ found a trend toward improved pulmonary index score when inhaled budesonide was added to oral prednisone in acute pediatric asthma. Guttman and cowork$\mathrm{ers}^{2}$ showed no effect when inhaled beclomethasone was added to intravenous methylprednisolone in adults with acute asthma. Scarfone and colleagues ${ }^{3}$ found nebulized dexamethasone was as effective as oral prednisone in the ED treatment of moderate asthma in children.

\section{Recommendations}

Current evidence does not support the routine use of inhaled steroids in all patients who present with acute asthma to the ED. However, inhaled steroid use in the ED may be beneficial in some patients. A systematic review or large, randomized controlled trial is warranted.

\section{References}

1. Sung L, Osmond MH, Klassen TP. Randomized, controlled trial of inhaled budesonide as an adjunct to oral prednisone in acute asthma. Acad Emerg Med 1998;5:209-13.

2. Guttman A, Afilalo M, Colacone A, Kreisman H, Dankoff J. The effects of combined intravenous and inhaled steroids (beclomethasone dipropionate) for the emergency treatment of acute asthma. Acad Emerg Med 1997;4:100-6.

3. Scarfone RJ, Loiselle JM, Wiley JF 2d, Decker JM, Henretig FM, Joffe MD. Nebulized dexamethasone versus oral prednisone in the emergency treatment of asthmatic children. Ann Emerg Med 1995;26:480-6.

\section{SElected Articles}

\section{Chest pain observation units for patients with unstable angina}

\section{Article chosen}

Farkouh ME, Smars PA, Reeder GS, Zinsmeister AR, Evans RW, Meloy TD, et al. A clinical trial of a chest-pain observation unit for patients with unstable angina. Chest Pain Evaluation in the Emergency Room (CHEER) Investigators. N Engl J Med 1998;339(26):1882-8.

\section{Objective}

To determine whether a chest pain observation unit (CPU) is a safe, effective and economical way to manage patients

\section{Reviewers}

Erica Rabin, MD; Michael Bullard, MD

University of Alberta, Edmonton, Alta.

Date studied: Jan. 16, 1999

This article has been peer reviewed.

with unstable angina who are at intermediate risk for shortterm cardiovascular events. 